CASE REPORT

\title{
A man with a DAX1/NROB1 mutation, normal puberty, and an intact hypothalamic-pituitary-gonadal axis but deteriorating oligospermia during long-term follow-up
}

\author{
Marie-Laure Raffin-Sanson ${ }^{1,2}$, Bérénice Oudet $^{1}$, Sylvie Salenave ${ }^{3}$, Sylvie Brailly-Tabard ${ }^{3,4}$, Martine Pehuet ${ }^{1}$, \\ Sophie Christin-Maitre ${ }^{5}$, Yves Morel $^{6}$ and Jacques Young ${ }^{3,4}$ \\ ${ }^{1}$ Service d'Endocrinologie, Assistance Publique- Hôpitaux de Paris, Hôpital Ambroise Paré, 92100 Boulogne, France, ${ }^{2}$ EA2493, Université de Versailles- \\ Saint Quentin en Yvelines, 78035 Versailles, France, ${ }^{3}$ Université Paris Sud 11, Service d'Endocrinologie et des Maladies de la Reproduction, Hôpital Bicêtre \\ and Assistance Publique- Hôpitaux de Paris, 94270 Le Kremlin Bicêtre cedex, France, ${ }^{4}$ INSERM U 693, F-94275 Le Kremlin Bicêtre, France, ${ }^{5}$ Service \\ d'Endocrinologie de la reproduction, Hôpital Saint Antoine et Faculté Paris VI, Paris, France and ${ }^{6}$ Biochimie Endocrinienne et Biologie Moléculaire, Hôpital \\ Debrousse, Lyon, France \\ (Correspondence should be addressed to J Young; Email: jacques.young@bct.aphp.fr)
}

\begin{abstract}
Objective: DAX1/NROB1 mutations cause primary adrenal insufficiency in early childhood and hypogonadotropic hypogonadism (HHG), leading to absent or incomplete sexual maturation. The aim of the study was to prospectively investigate gonadotrope and testicular functions in a patient carrying a DAX1 mutation, who had spontaneous puberty and normal virilization but oligospermia.

Case report: The proband was referred for infertility at the age of 32 years. He reported adrenal insufficiency diagnosed at the age of 19 years. Puberty started at the age of 13 years, with spontaneous virilization, growth spurt, and testicular growth. He reported normal libido and sexual function. Physical examination showed normal virilization, penile length, and testicular volume. However, semen samples showed severe oligospermia. Hormonal measurements confirmed adrenal insufficiency but showed a preserved hypothalamic-pituitary-gonadal axis with normal testosterone and inhibin B; basal and GNRH-stimulated gonadotropin levels and LH pulsatility were also normal. He fathered a first boy by in vitro fertilization and a second boy without medical assistance. As a nephew also had early adrenal insufficiency, the possibility of DAX1 mutation was raised. The same recurrent hemizygous nonsense mutation W39X was found in the proband, his nephew, and in an apparently asymptomatic brother who was found to have adrenal insufficiency, mild HHG, and azoospermia. Several evaluations of the proband over 20 years showed preserved testosterone levels and $\mathrm{LH}$ secretion but deteriorating oligospermia.

Conclusion: Long-term preservation of normal hypothalamic-pituitary-gonadal function in this patient, contrasting with his severe oligospermia, strongly suggests that DAX1 is required for human spermatogenesis, independently of its known role in gonadotropin secretion.
\end{abstract}

European Journal of Endocrinology 168 K45-K50

\section{Introduction}

DAX1 (for dosage-sensitive sex reversal, adrenal hypoplasia congenital (AHC) critical region on the $\mathrm{X}$ chromosome, gene 1; also called NROB1) mutations can cause congenital adrenal hypoplasia, a rare X-linked disorder associated with impaired development of the permanent zones of the adrenal cortex, usually revealed by primary adrenal failure in early infancy $(1,2)$. Hypogonadotropic hypogonadism (HHG) is also a hallmark of this disorder, usually recognized during adolescence because of the absence or interruption of normal pubertal development (1). HHG due to DAX1 mutation results from a combination of defective hypothalamic GNRH release and defective pituitary gonadotropin production (3). Abnormal spermatogenesis is also noted in patients with this mutation. However, it is unclear whether or not the effect of DAX1 mutations on human spermatogenesis is due solely to the associated gonadotropin deficiency. Milder forms of the disease have been described, with adrenal insufficiency sometimes occurring in childhood or even early adulthood. A few cases of partial HHG have also been described, with clear clinical and biological signs but no subjective symptoms $(4,5)$. Rare cases of apparently preserved gonadotropin secretion have been reported but not fully documented in patients with $D A X 1$ mutations $(6,7)$.

Here, we report the initial features and long-term outcome of a 32-year-old man diagnosed with adrenal insufficiency at the age of 19 years, who had oligospermia but persistently normal gonadotropic function. Molecular analysis revealed the same hemizygous 


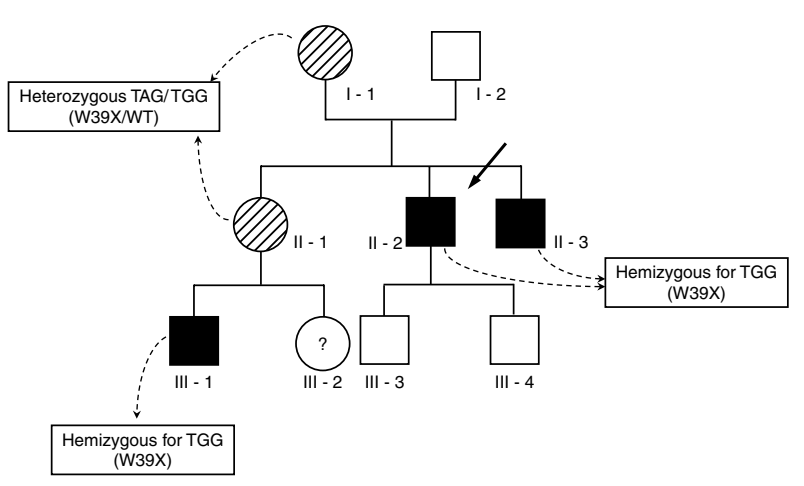

Figure 1 Pedigree of the family with patients affected by AHC with mutated DAX1 gene. Symbols represent males (squares), females (circles), affected subjects (solid symbols), carriers (dashed symbols), and the proband (arrow). DNA sequencing and mutation analysis were performed as described in (22), with minor modifications. WT, wild type. The propositus is indicated by an arrow.

N-terminal nonsense DAX1 mutation (W39X) in the proband, his young nephew and, a few years later, in his brother. The proband finally fathered two children. This is the first reported case of long-term preservation of gonadotrope function in a patient with markedly defective spermatogenesis due to DAX1 mutation.

\section{Case report}

The proband (subject II-2, Fig. 1) was referred to the Endocrinology Department of Bicêtre Hospital, Paris, at 32 years of age for evaluation of oligospermia. Adrenal insufficiency had been diagnosed at the age of 19 years, when he presented with fatigue and repeated episodes of sore throat and dizziness. He was treated effectively with hydrocortisone and fluorocortisone. He also reported being diagnosed with oligospermia at the age of 24 years, following failure to conceive, but denied further investigations at that time.

At the first hormonal evaluation at the age of 32 years, his height was $171 \mathrm{~cm}$, his weight $83 \mathrm{~kg}$, and his blood pressure 130/70 mmHg. Physical examination revealed increased skin pigmentation. Penile length was normal $(10 \mathrm{~cm})$. Testicular volume was $20 \mathrm{ml}$ bilaterally (normal range $12-30 \mathrm{ml}$ ). He reported spontaneous onset of puberty at the age of 13 years, with normal virilization, growth spurt, and testicular growth. He reported normal libido, erections, and sexual function. At the time of the initial investigations, at 30 years of age, he was taking hydrocortisone $30 \mathrm{mg} /$ day and $9 \alpha$-fluorocortisone $100 \mu \mathrm{g} /$ day. Biological and hormonal explorations confirmed the primary adrenal insufficiency (Table 1). Adrenoleukodystrophy was ruled out by a normal level of C24/C22 very-long-chain fatty acids. Computed tomography showed bilateral adrenal atrophy. During this period, the proband's sister (subject II-1, Fig. 1) gave birth to a boy who had normal descended testes and normal genitalia (subject III-1, Fig. 1) but who had an adrenal crisis ( $\mathrm{Na} 122 \mathrm{mmol} / \mathrm{l}, \mathrm{K}+7.7 \mathrm{mmol} / \mathrm{l}$ ) during the second week of life. The newborn had elevated plasma ACTH and renin levels, confirming primary adrenal insufficiency. The possibility of a DAX1 mutation was therefore raised and molecular studies of the patient and his nephew were performed with the patient's and parents' informed consent. A nonsense loss-of-function (8) mutation in the DAX1 gene, resulting in an aminoterminal truncated protein (W39X: TAG $\rightarrow$ TGG), was found in both subjects. The same mutation was found

Table 1 Hormonal and gonadal evaluation of the proband (subject II-2 in Fig. 1) at diagnosis and during follow-up. The brother (subject II-3 in Fig. 1) was evaluated at diagnosis.

\begin{tabular}{|c|c|c|c|c|c|c|c|c|c|}
\hline & \multicolumn{7}{|c|}{ Proband } & \multirow{2}{*}{$\begin{array}{c}\text { Brother } \\
2011 \\
\text { (36 years) }\end{array}$} & \multirow[b]{2}{*}{ Normal range } \\
\hline & $\begin{array}{c}1987 \\
\text { (23 years) }\end{array}$ & $\begin{array}{c}1997 \\
\text { (32 years) }\end{array}$ & $\begin{array}{c}2000 \\
\text { (35 years) }\end{array}$ & $\begin{array}{c}2002 \\
\text { (37 years) }\end{array}$ & $\begin{array}{c}2003 \\
\text { (39 years) }\end{array}$ & $\begin{array}{c}2008 \\
\text { (43 years) }\end{array}$ & $\begin{array}{c}2012 \\
\text { (47 years) }\end{array}$ & & \\
\hline Cortisol (0800 h) & - & 0.5 & - & 0.6 & 0.6 & $<0.2$ & 0.5 & 10 & 9-23 ( $\mu \mathrm{g} / 100 \mathrm{ml})$ \\
\hline ACTH (0800 h) & - & 2315 & - & 1671 & 1414 & 2843 & 2014 & 749 & $10-50(\mathrm{pg} / \mathrm{ml})$ \\
\hline DHEAS & - & 361 & - & 249 & 268 & 200 & - & 147 & $800-4500(\mathrm{ng} / \mathrm{ml})$ \\
\hline $\begin{array}{l}\text { Renin (supine/ } \\
\text { upright) }\end{array}$ & - & $464 / 690$ & - & $-/ 320$ & $310 / 310$ & 491/- & 500 & - & $3-16 / 3-33(\mathrm{pg} / \mathrm{ml})$ \\
\hline $\begin{array}{l}\text { Aldosterone } \\
\text { (supine/upright) }\end{array}$ & - & $75 / 76$ & - & $-/ 65$ & $60 / 70$ & $13 /-$ & 30 & $12 / 28$ & $\begin{array}{l}\text { 15-150/35-350 } \\
(\mathrm{pg} / \mathrm{ml})\end{array}$ \\
\hline Testosterone & 7.7 & 5.5 & 6.1 & 5.2 & 5.4 & 4.2 & 5.3 & 2.4 & $3.5-8.5(\mathrm{ng} / \mathrm{ml})$ \\
\hline $\begin{array}{l}\text { LH (basal/ } \\
\quad \text { stimulated }^{\mathrm{a}} \text { ) }\end{array}$ & $6.3 /-$ & $2.4 / 9.4$ & $1.7 / 8.6$ & - & $1.3 / 10.5$ & $2.6 / 7.5$ & $1.8 /-$ & $2 / 5.6$ & $\begin{array}{l}1.5-12.4 / 8.0-25 \\
\text { (IU/I) }\end{array}$ \\
\hline $\begin{array}{l}\text { FSH (basal/ } \\
\text { stimulated }^{\mathrm{a}} \text { ) }\end{array}$ & $5.8 /-$ & $4.1 / 5.6$ & $3.4 / 5.0$ & - & $1.2 / 4.0$ & $4.4 / 8.7$ & $4.4 /-$ & $5.9 / 7.3$ & $\begin{array}{l}1.7-8.6 / 2.0-9.0 \\
(\mathrm{IU} / \mathrm{l})\end{array}$ \\
\hline Inhibin B & - & - & 148 & 123 & 113 & 38 & - & 74 & 80-270 (pg/ml) \\
\hline Sperm count & $4 \times 10^{6}$ & $2.3 \times 10^{6}$ & $0.7 \times 10^{6}$ & $0.05 \times 10^{6}$ & - & - & - & 0 & $>20 \times 10^{6} / \mathrm{ml}$ \\
\hline
\end{tabular}

Serum LH and FSH were measured by immunofluorometric assay, testosterone levels by RIA, and inhibin B levels with an ELISA method as described previously (24). -, not done.

${ }^{a}$ GNRH (100 $\mu \mathrm{g}$ i.v.), the GNRH challenge test was performed as reported in (24). Plasma renin, aldosterone, DHEAS, ACTH, and cortisol levels were determined with commercial RIA kits. 

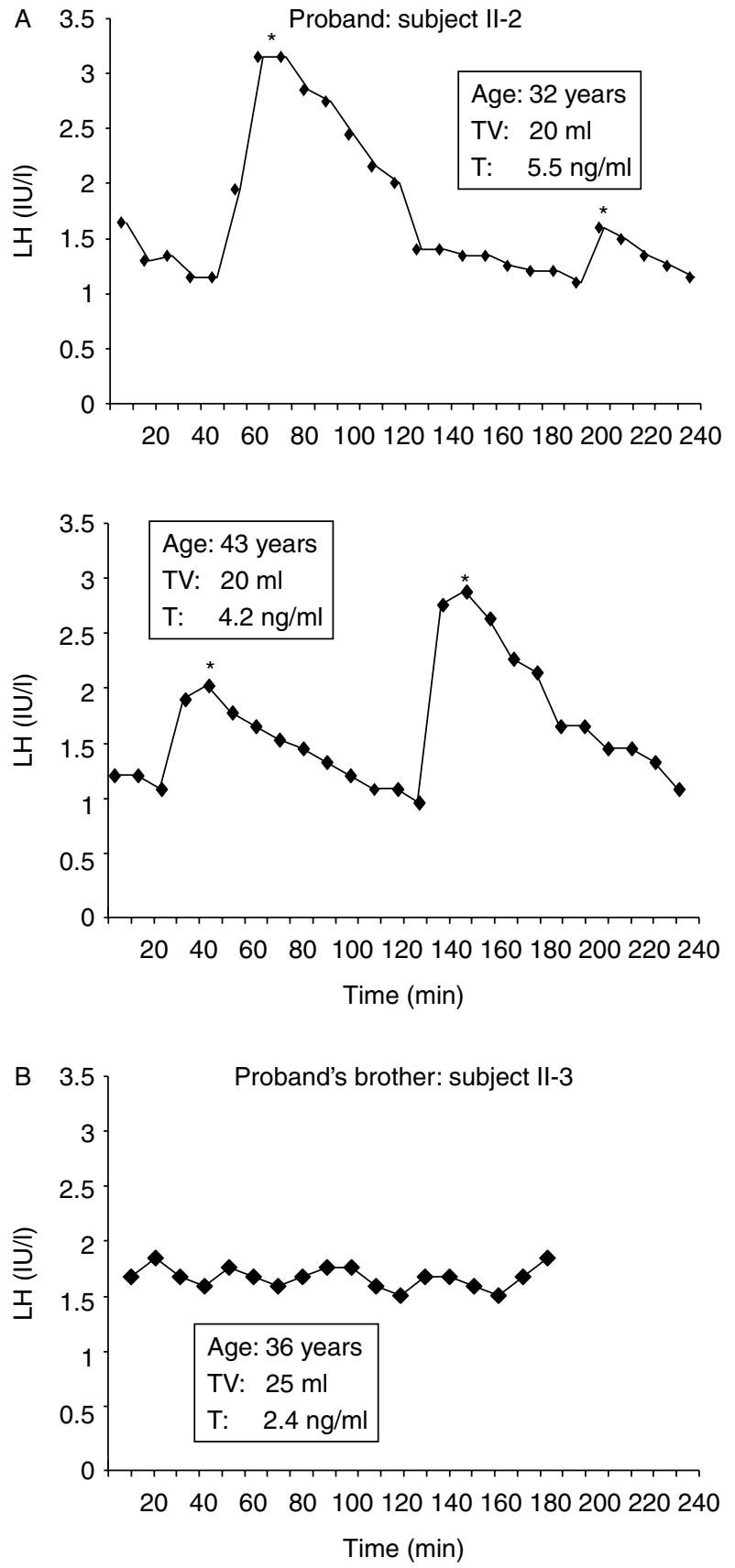

Figure 2 (A) Endogenous serum LH levels (closed symbols) in the propositus (subject II-2, Fig. 1) at an 11-year interval. LH pulsatility was evaluated at 32 years (upper panel) and 43 years (middle panel). LH was measured at 10-min intervals for $4 \mathrm{~h}$ and analyzed with the Thomas algorithm (24). Asterisks denote detectable LH pulses. LH, total testosterone, and inhibin B were measured as indicated in Table 1. (B) Endogenous serum LH levels in the propositus' brother (subject II-3, Fig. 1). LH pulsatility was evaluated at 36 years. LH was measured at 10-min intervals for $4 \mathrm{~h}$ and analyzed with the Thomas algorithm (24). No LH pulses were detected. LH, total testosterone, and inhibin B were measured as indicated in Table 1 and in (24). TV, testicular volume. in the unaffected proband's mother (subject I-1, Fig. 1) and sister (subject II-1, Fig. 1), and both were heterozygous.

Results of longitudinal evaluation of the proband are shown in Table 1 and Fig. 2A. The plasma total testosterone level remained normal throughout the 25 years of follow-up, indicating LH-driven preserved Leydig cell function. By contrast, oligospermia tended to worsen over time (Table 1). Likewise, inhibin B levels showed a fall over time, indicating impaired Sertoli cell function. We also observed a decrease in testicular volume (15 ml in 2012).

Analysis of endogenous pulsatile LH secretion at the age of 32 years showed a normal mean LH level and a preserved frequency (two pulses $/ 4 \mathrm{~h}$, normal $4 \pm 0.8 / 8 \mathrm{~h}$ ). Eleven years later, at the age of 43 years, testosterone and LH secretion showed a similar pattern, further indicating preserved gonadotropic function (Fig. 2A).

Because the testosterone and gonadotropin levels were normal, hormonal treatment was not proposed. After genetic counseling, the couple was offered reproductive assistance because of severe oligospermia. The patient fathered a first healthy son (subject III-3, Fig. 1) at the age of 33 years, after in vitro fertilization of his wife's oocytes. A second healthy son was born 2 years later (subject III-4, Fig. 1), after spontaneous conception. The younger brother (subject II-3, Fig. 1) denied evaluation until the age of 36 , when he was referred to the Endocrinology Department of Ambroise Paré Hospital for exploration of azoospermia. Physical examination revealed normal weight and blood pressure, complete virilization, and normal penile length $(11 \mathrm{~cm})$ and testicular volume $(25 \mathrm{ml})$. He reported normal sexual function. The testosterone level was rather low with a subnormal LH response to GNRH stimulation (Table 1) and apulsatile LH secretion (Fig. 2B). Blood electrolytes were normal. However, an abnormal cortisol response to the standard-dose $(250 \mu \mathrm{g}$ i.v. $)$ cortrosyn test (peak: $14.0 \mu \mathrm{g} / 100 \mathrm{ml}, n>27)$, elevated ACTH, and a low supine aldosterone plasma level revealed mild asymptomatic adrenal insufficiency. Hydrocortisone and fludrocortisone administration were recommended. DAX1 analysis confirmed that he carried the W39X familial mutation. After 5 months of combined gonadotropin treatment, his total testosterone was normal, $7.3 \mathrm{ng} / \mathrm{ml}(\mathrm{N} ; 2.5-8.4)$, his FSH serum level was $2.3 \mathrm{IU} / \mathrm{l}$, and his inhibin B level normalized to $139 \mathrm{pg} / \mathrm{ml}$ but azoospermia persisted.

\section{Discussion}

We describe a man with a DAX1 nonsense mutation associated with late-onset adrenal insufficiency and normal gonadotropic function but severe oligospermia. DAX1-mutated patients usually have severe adrenal 
insufficiency diagnosed during the first weeks of life (9) or in childhood. In rare cases, onset occurs in early adulthood $(4,10,11)$, sometimes with prominent effects on mineralocorticoid function $(6,8,9,10)$. The phenotypes of the proband, his brother, and his nephew illustrate the different possible adrenal consequences of identical DAX1 mutations $(12,13)$. The adrenal phenotypes of the proband and his brother are reminiscent of the mouse model, in which adrenal failure is a late event: after a transient period of enhanced adrenal susceptibility to ACTH, aging Dax 1 knockout mice display decreased adrenal steroidogenic capacity and adrenal cell proliferation (14). We do not know whether the proband and his brother had a period of elevated adrenal steroid hormone production before adrenal failure. However, long-term follow-up of subject II-3, who has partly preserved adrenal function at the age of 35 years, will show whether adrenal steroidogenic function declines further with aging. This would argue for a role of DAX1 in the maintenance of adrenal progenitor cells in humans, as in mice.

The gonadotropic phenotype of this patient is most unusual. HHG in boys with DAX1 mutations is usually severe and revealed by absent or impaired pubertal development. Some patients also have unilateral or bilateral cryptorchidism (9), indicating that gonadotropin secretion has been deficient since as early as intrauterine life (15). The most striking feature of the proband reported here is the absence of hypogonadism, with normal puberty and persistently normal spontaneous LH pulsatile secretion and testosterone levels. Some reports have described partial pubertal development and oligospermia in rare patients with DAX1 mutations, in whom low serum testosterone concentrations indicated partial gonadotropic deficiency $(4,10)$. More recently, men with missense mutations located in the amino-terminal portion of DAX1 (W105C and $\mathrm{C} 200 \mathrm{~W}$ ) were reported to have an apparently normal hypothalamic-pituitary-gonadal axis with no signs or symptoms of hypogonadism $(6,7)$. In these families, the disease was revealed by mild adrenal disorders in the affected probands, whereas male relatives carrying the same mutation seemed to have apparently normal pubertal development and sexual function $(6,7)$. However, the pathophysiological effect of the C200W mutation is still unclear, and overall, these reports did not include exhaustive clinical data on the reproductive phenotype, or detailed investigations of pituitary gonadotropic and testicular hormone secretion. In addition, no specific information was provided on testicular exocrine function (sperm count) in these 'asymptomatic' men, or on the natural history of their reproductive function $(6,7)$.

As far as we are aware, this is the first report of a DAX1 mutation in a patient with documented normal gonadotrope function (normal testosterone secretion, normal basal and stimulated LH secretion and pulsatility, and normal testicular volume). By contrast, this patient exhibited impaired spermatogenesis, with gradually worsening oligospermia and Sertoli cell endocrine dysfunction. This association between a normal gonadotrope axis and severe testicular dysfunction further suggests that, as in mice, DAX1 deficiency could cause progressive alteration of the testicular germinal epithelium, independently of gonadotropin and testosterone production. Studies of Ahch (Dax 1) knockout mice (16) and patients with AHC (3) had already suggested that DAX1 mutations could directly affect spermatogenesis. First, targeted disruption of Ahch (Dax 1) in mice results in infertility despite apparently normal gonadotropin and adrenal steroid production (16). Evaluation of the male reproductive tract in Dax 1deficient mice by light and electron microscopy revealed that the rete testis is blocked by aberrantly located Sertoli cells, creating a tailback of necrosing sperm (16).

Secondly, azoospermia has been reported in most patients with classical X-linked AHC caused by DAX1 mutations, and attempts to induce fertility with exogenous gonadotropins or GNRH have been unsuccessful $(8,17,18)$. Thus, this near-universal failure of gonadotropin treatment to induce spermatogenesis in men with classical $D A X 1$ phenotype associated with the Dax 1 mice phenotype are in favor of the hypothesis of a direct deleterious effect of DAX1 mutations on human spermatogenesis. Our case therefore further indicates that the mouse model is relevant to human pathology.

As indicated earlier, primary testicular dysfunction in patients with DAX1 mutation is usually considered to be a defect that cannot be restored by gonadotropin treatment. However, a case of paternity after TESE-ICSI was recently described in a patient with a $D A X 1$ mutation and classical AHC, HHG, and azoospermia (19), giving hope to men with such mutations. Interestingly, the proband described here fathered a child at 35 years of age, when his sperm count was only $0.7 \mathrm{million} / \mathrm{ml}$. It has previously been demonstrated that conception can occur despite a very low sperm count, as for example in patients with HHG receiving gonadotropin therapy (20). The defective spermatogenesis in this patient is worsening with age, suggesting that semen preservation should be offered to young men with DAX1 mutations and mild spermatogenesis.

Most DAX1 mutations described so far $(6,21,22)$ lead to an absent or truncated protein, resulting in a severe phenotype. Missense mutations, reported in about $20 \%$ of cases, are associated with more variable reproductive phenotypes $(4,6,10,12)$. The recurrent $(5,11)$ W39X mutation found in our patient and in his affected brother leads to an amino-truncated DAX1 protein generated from an alternative in-frame translation start site and retaining partial activity (8). As previously reported for another amino-terminal nonsense close mutation, Q37X, the W39X mutation was also associated with a mild phenotype $(5,8)$. Thus, it has been reported that gonadotrope function is often preserved in patients with mutations resulting in a 
N-terminal truncated DAX1 protein $(5,6,7,8)$ that may provide sufficient DAX1 activity for gonadotrope cell development and function. We must, however, specify that the W39X mutation can also be associated with partial or complete gonadotropin deficiency as in the proband's brother described here or in the patients reported by Guclu et al. (11).

Testicular biopsy has been performed in a small number of DAX1-mutated men, showing diverse histological aspects $(8,17,19,23)$. The first biopsy reported in an adult male was performed at the age of 27 , following 7 years of hCG treatment. It revealed a Sertoli cell-only syndrome aspect with rare spermatogonia and no apparent ongoing spermatogenesis (17). A second report concerned a 20-year-old patient with a milder phenotype who had been treated for 6 months with exogenous gonadotropins (8). Biopsy revealed disorganization of the normal tubule structure and abnormal proliferation of interstitial tissue, as well as moderate Leydig cell hyperplasia, possibly related to chronic hCG administration. Interestingly, postmortem examination of a neonate who died at 23 days revealed normal testicular histology (23) with the presence of well-defined seminiferous testis cords containing numerous Sertoli cells and germ cells. This is compatible with a progressive deterioration of testicular function due to DAX1 mutations, as observed in our patient. Finally, Frapsauce et al. recently reported severe hypospermatogenesis in an adult, with a majority of germ cells arrested at the spermatocyte stage. Although most of the tubules were depleted of mature spermatozoa, some tubules exhibited focal complete spermatogenesis and rare mature spermatozoa that could be retrieved from mechanically dilacerated testicular tissue and used to successfully perform TESE/ICSI (19).

In conclusion, this case report further extends the clinical phenotype of $D A X 1$ mutations to include isolated infertility with normal pubertal development and long-term integrity of the hypothalamic-pituitarygonadal axis. The association of this phenotype with an adrenal insufficiency should evoke a DAX1 mutation. The severely impaired spermatogenesis in this patient adds direct evidence to the argument that in humans, as in rodents, DAX1 affects testicular function independently of its effects on gonadotropin secretion. This and other observation indicates that DAX1 mutations do not always result in male sterility but we show here that semen preservation should be offered to young men with DAX1 mutations and mild spermatogenesis.

\section{Declaration of interest}

The authors declare that there is no conflict of interest that could be perceived as prejudicing the impartiality of the research reported.

\section{Funding}

This work was supported by the Assistance Publique-Hôpitaux de Paris, France.

\section{References}

1 Muscatelli F, Strom TM, Walker AP, Zanaria E, Recan D, Meindl A, Bardoni B, Guioli S, Zehetner G, Rabl W et al. Mutations in the DAX1 gene give rise to both X-linked adrenal hypoplasia congenita and hypogonadotropic hypogonadism. Nature 1994 372 672-676. (doi:10.1038/372672a0)

2 Zanaria E, Muscatelli F, Bardoni B, Strom TM, Guioli S, Guo W, Lalli E, Moser C, Walker AP, McCabe ER et al. An unusual member of the nuclear hormone receptor superfamily responsible for X-linked adrenal hypoplasia congenita. Nature 1994372 635641. (doi:10.1038/372635a0)

3 Jadhav U, Harris RM \& Jameson JL. Hypogonadotropic hypogonadism in subjects with DAX1 mutations. Molecular and Cellular Endocrinology 2011346 65-73. (doi:10.1016/j.mce. 2011.04.017)

4 Tabarin A, Achermann JC, Recan D, Bex V, Bertagna X, ChristinMaitre S, Ito M, Jameson JL \& Bouchard P. A novel mutation in DAX1 causes delayed-onset adrenal insufficiency and incomplete hypogonadotropic hypogonadism. Journal of Clinical Investigation 2000105 321-328. (doi:10.1172/JCI7212)

5 Binder G, Wollmann H, Schwarze CP, Strom TM, Peter M \& Ranke MB. X-linked congenital adrenal hypoplasia: new mutations and long-term follow-up in three patients. Clinical Endocrinology 200053 249-255. (doi:10.1046/j.1365-2265. 2000.01038.x)

6 Verrijn Stuart AA, Ozisik G, de Vroede MA, Giltay JC, Sinke RJ, Peterson TJ, Harris RM, Weiss J \& Jameson JL. An amino-terminal DAX1 (NROB1) missense mutation associated with isolated mineralocorticoid deficiency. Journal of Clinical Endocrinology and Metabolism 200792 755-761. (doi:10.1210/jc.2005-2429)

7 Bernard P, Ludbrook L, Queipo G, Dinulos MB, Kletter GB, Zhang YH, Phelan JK, McCabe ER, Harley VR \& Vilain E. A familial missense mutation in the hinge region of $D A X 1$ associated with late-onset AHC in a prepubertal female. Molecular Genetics and Metabolism 200688 272-279. (doi:10.1016/j.ymgme.2005. 12.004)

8 Ozisik G, Mantovani G, Achermann JC, Persani L, Spada A, Weiss J, Beck-Peccoz P \& Jameson JL. An alternate translation initiation site circumvents an amino-terminal DAX1 nonsense mutation leading to a mild form of X-linked adrenal hypoplasia congenita. Journal of Clinical Endocrinology and Metabolism $2003 \mathbf{8 8} 417-423$. (doi:10.1210/jc.2002-021034)

9 Peter M, Viemann M, Partsch CJ \& Sippell WG. Congenital adrenal hypoplasia: clinical spectrum, experience with hormonal diagnosis, and report on new point mutations of the DAX1 gene. Journal of Clinical Endocrinology and Metabolism $1998 \mathbf{8 3}$ 2666-2674. (doi:10.1210/jc.83.8.2666)

10 Mantovani G, Ozisik G, Achermann JC, Romoli R, Borretta G, Persani L, Spada A, Jameson JL \& Beck-Peccoz P. Hypogonadotropic hypogonadism as a presenting feature of late-onset X-linked adrenal hypoplasia congenita. Journal of Clinical Endocrinology and Metabolism 200287 44-48. (doi:10.1210/jc.87.1.44)

11 Guclu M, Lin L, Erturk E, Achermann JC \& Cangul H. Puberty, stress, and sudden death. Lancet 2010376 1512. (doi:10.1016/ S0140-6736(10)61153-1)

12 Ahmad I, Paterson WF, Lin L, Adlard P, Duncan P, Tolmie J. Achermann JC \& Donaldson MD. A novel missense mutation in $D A X 1$ with an unusual presentation of X-linked adrenal hypoplasia congenita. Hormone Research 200768 32-37. (doi:10.1159/000099835)

13 Landau Z, Hanukoglu A, Sack J, Goldstein N, Weintrob N, Eliakim A, Gillis D, Sagi M, Shomrat R, Kosinovsky EB et al. Clinical and genetic heterogeneity of congenital adrenal hypoplasia due to NROB1 gene mutations. Clinical Endocrinology 200972 448-454. (doi:10.1111/j.1365-2265.2009.03652.x)

14 Scheys JO, Heato JH \& Hammer GD. Evidence of adrenal failure in aging Dax1-deficient mice. Endocrinology 2011152 3430-3439. (doi:10.1210/en.2010-0986) 
15 Bouvattier C, Maione L, Bouligand J, Dodé C, Guiochon-Mantel A \& Young J. Neonatal gonadotropin therapy in male congenital hypogonadotropic hypogonadism. Nature Reviews. Endocrinology 20118 172-182. (doi:10.1038/nrendo.2011.164)

16 Yu RN, Ito M, Saunders TL, Camper SA \& Jameson JL. Role of Ahch in gonadal development and gametogenesis. Nature Genetics 1998 20 353-357. (doi:10.1038/3822)

17 Seminara SB, Achermann JC, Genel M, Jameson JL \& Crowley WF. $\mathrm{X}$-linked adrenal hypoplasia congenita: a mutation in DAX1 expands the phenotypic spectrum in males and females. Journal of Clinical Endocrinology and Metabolism $1999 \quad 84$ 4501-4509. (doi:10.1210/jc.84.12.4501)

18 Mantovani G, De Menis E, Borretta G, Radetti G, Bondioni S, Spada A, Persani L \& Beck-Peccoz P. DAX1 and X-linked adrenal hypoplasia congenita: clinical and molecular analysis in five patients. European Journal of Endocrinology 2006154 685-689. (doi:10.1530/eje.1.02132)

19 Frapsauce C, Ravel C, Legendre M, Sibony M, Mandelbaum J, Donadille B, Achermann JC, Siffroi JP \& Christin-Maitre S. Birth after TESE-ICSI in a man with hypogonadotropic hypogonadism and congenital adrenal hypoplasia linked to a DAX-1 (NROB1) mutation. Human Reproduction 201126 724-728. (doi:10.1093/ humrep/deq372)

20 Burris A, Clark R, Vantman D \& Sherins R. A low sperm concentration does not preclude fertility in men with isolated hypogonadotropic hypogonadism after gonadotropin therapy. Fertility and Sterility $198850343-347$.
21 Lin L, Gu WX, Ozisik G, To WS, Owen CJ, Jameson JL \& Achermann JC. Analysis of DAX1 (NROB1) and steroidogenic factor-1 (NR5A1) in children and adults with primary adrenal failure: ten years' experience. Journal of Clinical Endocrinology and Metabolism 200691 3048-3054. (doi:10.1210/jc. 2006-0603)

22 Pelissier P, Merlin E, Prieur F, David M, Malpuech G, Forest MG, Morel Y, Nicolino M, Richard O \& Stephan JL. Adrenal hypoplasia congenita: four new cases in children. Archives de Pediatrie 2005 12 380-384. (doi:10.1016/j.arcped.2005.01.007)

23 Brown P, Scobie GA, Townsendt J. Bayne RA, Seckl JR, Saunders PT \& Anderson RA. Identification of a novel missense mutation that is damaging to DAX1 repressor function as a nonsense mutations. Journal of Clinical Endocrinology and Metabolism 200388 1341-1349. (doi:10.1210/jc.2002021560)

24 Bouligand J, Ghervan C, Tello JA, Brailly-Tabard S, Salenave S, Chanson P, Lombes M, Millar RP, Guiochon-Mantel A \& Young J. Isolated familial hypogonadotropic hypogonadism and a GNRH1 mutation. New England Journal of Medicine $20093602742-2748$. (doi:10.1056/NEJMoa0900136)

Received 6 December 2012

Revised version received 27 January 2013

Accepted 4 February 2013 